\title{
ELECTRONIC WORD OF MOUTH INTENSION IN KALIBIRU NATURAL TOURISM KULON PROGO
}

\author{
Negara Dimass Harimurti Candra*, Yuliati Lilik Noor, Sartono Bagus \\ School of Business, Bogor Agricultural University, Indonesia \\ ${ }^{*}$ E-mail: dimasshcn22@gmail.com
}

\begin{abstract}
Nowadays social media is used to find information about a tourist destination. Information on social media can be like photos of visitors or comments about visitors' experiences after visiting a tourist destination. This information will be used by others as their reference in choosing tourist destination to be visited. The intention of doing an EWOM is related to someone's desire to tell their experiences in cyberspace. This study aims to analyze the effect between perceived electronic word of mouth and service quality with destination image, destination image with the intention to do an EWOM, and motivation with the intention to do an EWOM. This research was conducted at Kalibiru Nature Tourism. The method used is descriptive by distributing questionnaires to 350 respondents. Data analysis using SPSS23 and SEM software with LISREL 8.80 software. Obtained a positive and insignificant relationship between perceived EWOM and destination image, then there is a positive and significant relationship between service quality with destination image, destination image with the intention to do an EWOM, and motivation with the intention to do an EWOM. Service quality has an important role in creating a good image of Kalibiru Nature Tourism. If the image of Nature Tourism has been assessed well by visitors, it will increase the desire of visitors to do EWOM on social media that contains recommendations for visiting Kalibiru Nature Tourism. The quality of existing services in Kalibiru Nature Tourism is good, so it needs to be maintained.
\end{abstract}

\section{KEY WORDS}

Destination image, service quality, motivation, social media, tourism.

Indonesia is a country that has a very large area and Indonesia has many places with very beautiful scenery. The natural beauty that is owned today is widely used as a tourist attraction that can be enjoyed by visitors or tourists. In 2018 Indonesia's tourism sector has generated foreign exchange of Rp. 224 trillion, up from Rp. 202.13 trillion in 2017. This increase was due to promotions in international festivals, exhibitions and sales missions, collaboration with various airlines, and doing famtrips for the media, journalists, bloggers, influencers, and vloggers (Kemenpar, 2018).

Yogyakarta Special Region Province is one of the provinces that has many tourist destinations, ranging from natural and non-natural tourism (historical, spiritual, and others). The number of tourists coming to Yogyakarta Special Region Province from 2013-2017 has increased. In 2017, foreign tourists visited 397,951 people and local tourists visited 4,831,347 people (Dinas Pariwisata DIY, 2018).

Nowadays social media is also used to find information about a tourist destination. Information on social media can include uploading photos of visitors or commenting on visitors' experiences after visiting a tourist destination. This information will be used by others as their reference in choosing tourist attractions to be visited.

In satisfying the visitors, each tourist destination will try to provide the best quality of service. Service quality is the heart of tourism marketing. Many researchers also link service quality with the image of a tourist destination. The results of these studies also prove that service quality affects the image of a tourist destination (Kayat and Hai, 2013; Akroush et al., 2016; Moon et al., 2013; Sunarti and Hartini S., 2015).

Judging from the previous explanation, it can be seen that the image of a tourist destination has an important role in the tourism industry. One of the advantages of a tourist 
destination that has a good image is the desire of visitors to recommend these tourist destinations to others. The desire to recommend shows that visitors are satisfied with what they have got when visiting the tourist destination. At the moment, the form of the recommendation can be seen from the content uploaded by visitors to their social media accounts. Several studies have shown that the image of a tourist destination can influence visitors' intentions to conduct EWOM (Papadimitriou et al., 2015; Shafiee et al., 2016).

Every individual in conducting EWOM on social media is based on the motivation that is in him or her. There are several studies that prove that there are several motivational factors that encourage individuals to do EWOM (Thurau et al., 2004; Magalhaes and Musallam, 2014).

Kalibiru Nature Tourism is a theme of nature scenery. Management of Kalibiru Nature Tourism revealed that there were not as many visitors coming to Kalibiru at the beginning of the boom. This can be seen from the data on the number of visitors in Figure 1.

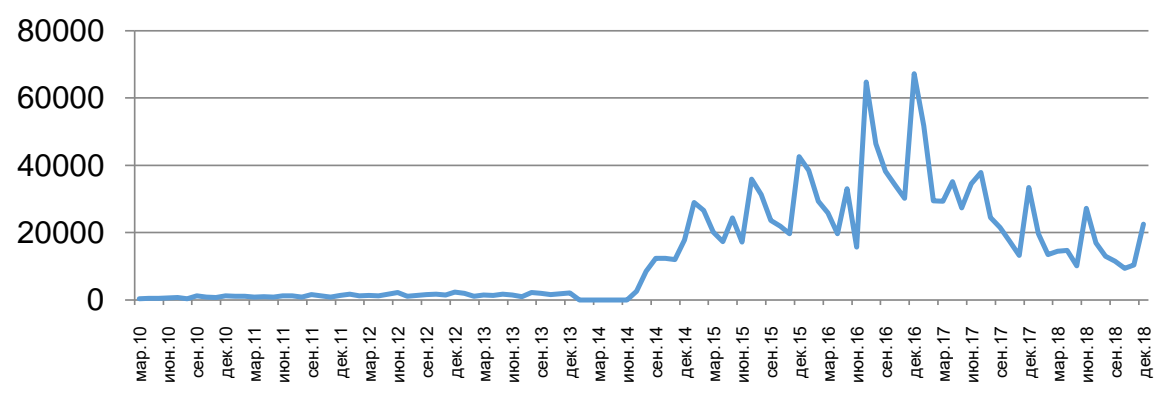

Figure 1 - Data of Kalibiru Nature Tourism Visitor Source: Management of Kalibiru Nature Tourism (Processed)

In increasing the number of visitors, the management of the Kalibiru Nature Tourism has done several ways to improve its quality, such as improving and completing facilities, setting affordable prices, and others. Many studies have shown that the quality of services provided by a tourist site can affect the image of the tourist site. This needs to be investigated whether the quality of services provided by Kalibiru tourism places a positive impact on the image of Kalibiru Nature Tourism.

\section{LITERATURE REVIEW}

In a study conducted by Jalivand, et al. (2012) in Isfahan tourist attractions, it is proven that EWOM can influence the image of the tourist attractions, tourist attitudes, and intentions to visit tourist attractions. While research conducted by Prayogo et al. (2016), shows that EWOM has a positive relationship with the image of Malioboro tourist attractions, but not significantly.

One study conducted in Alanya Turkey by Tosun et al. (2015) shows that the quality of services felt by visitors has positive effect on the image of the tourist attractions. The quality of these services include accommodation owned, friendliness of local residents and employees, activities provided by tourist attractions, and the language used in these tourist attractions. There are many studies that prove that the quality of service received by visitors can affect the image of a tourist place (Kayat and Hai, 2014; Akroush et al., 2016; Moon et al., 2013; Sunarti and Hartini S., 2015).

In a study conducted by Shafiee, et al. (2016), it was found that all images of a destination affect the intention of visitors to visit again and the intention of visitors to do EWOM on foursquare. The research was conducted in six major cities namely, Tehran, Mashhab, Rasht, Shiraz, Isfahan, and Tabriz. Research conducted by Papadimitriou et al. (2015) also found that the cognitive and affective image of a destination has a positive effect on visitor intentions to do EWOM. The research was conducted in several cities in Greece. 
In a study conducted by Magalhaes and Musallam (2014), it was explained that there are several factors/motivations that can influence a person's desire to do EWOM on Twitter. There are four factors that are most influential, namely: caring for others, extra-positive/selfdevelopment, venting negative feelings, and helping the company.

Based on the description above, it is suspected that EWOM and service quality can affect the destination image. In addition, destination image and motivation can affect the intention of visitors to do EWOM. Based on this explanation, the research conceptual framework can be illustrated in Figure 2.

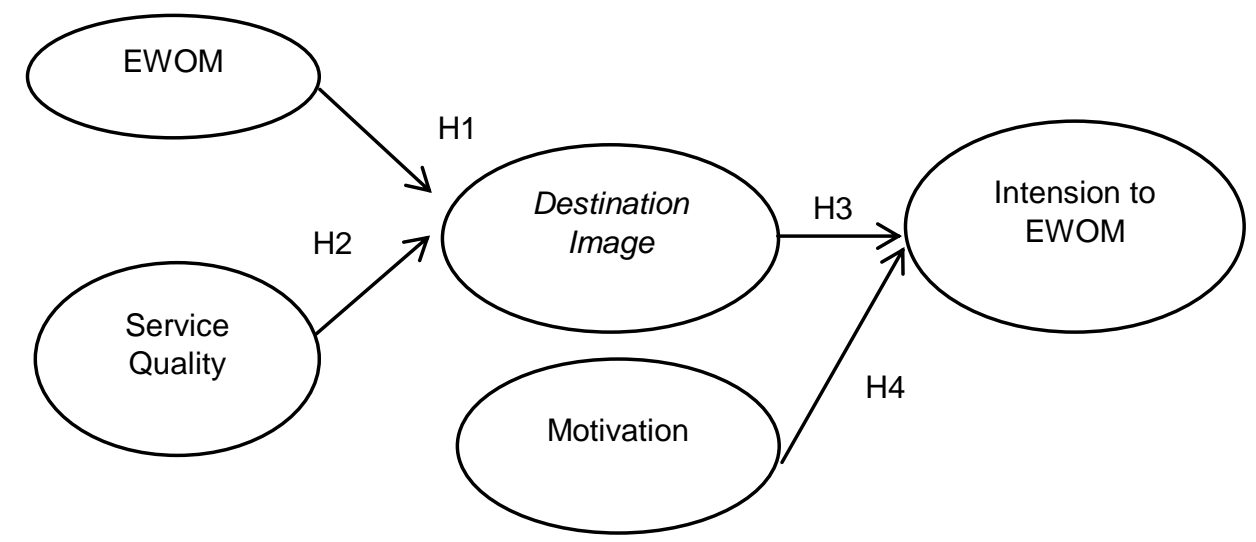

Figure 2 - Conceptual Research Framework

Based on a conceptual framework, the hypotheses to be tested in this study are:

- H1: EWOM has a positive and significant effect on destination image;

- H2: Service quality has a positive and significant effect on destination image;

- H3: Destination image has a positive and significant effect on the intention to conduct EWOM;

- H4: Motivation has a positive and significant effect on the desire to do EWOM.

\section{METHODS OF RESEARCH}

This research took place in the Kalibiru Tourism area, Kulon Progo Regency, Special Region of Yogyakarta. The research was carried out for 3 months from April to July 2019. The approach used in this study is a quantitative approach with a survey method and involves respondents who visited the Kalibiru Tourism site.

In this study, the respondents used were visitors who came to Kalibiru who had social media accounts, were visitors who made the decision to come to Kalibiru, and were active in using social media. According to Augusty (2006), Population is a combination of all elements that formed events, things, or people who have similar characteristics that are the center of attention of researchers, because they are seen as the universe of research.

Samples are part of a population. Populations can contain a large amount of data which results in an impossible or difficult assessment of all such data, so the assessment is carried out on only the samples (Harinaldi, 2005). In determining the number of samples, according to Ferdinand (2005) the sample size is 5-10 times the number of indicator variables, so the number of samples is between $64 \times 5=320$ respondents up to $64 \times 10=$ 640 respondents. This study used a total sample of 350 respondents.

The sampling method used in this study is accidental sampling or commonly called conveiniences sampling. The data obtained were then processed using SPSS 23 and SEM software using LISREL 8.80.

This study uses five variables, namely EWOM variable, service quality consisting of five dimensions (tangible, reliability, responsiveness, assurance, and empathy), destination image, motivation which consists of seven dimensions (venting negative feeling, concern of others, posituve self enhancement, helping the company, collective power over companies, influence of others, and advice seeking to get information), and the intension to do an 
EWOM. The EWOM variable has 5 indicator variables, service quality has 24 indicator variables, destination image has 5 indicator variables, motivation has 26 indicator variables, and the desire to do EWOM has 3 indicator variables.

\section{RESULTS AND DISCUSSION}

In the data analysis process, each indicator variable and dimension that has a loading factor value $<0.50$ is declared invalid and will be eliminated. Indicator variables that were eliminated included EWM1, EWM2, EWM3, EWM4, KJRL1, PSE1, PSE3, CPO3 and DI2. While the dimensions eliminated include VNF and COF. After elimination, a reliability test is performed by calculating the value of Construct Reliability (CR). Each variable has a CR value $>0.5$ so that all variables are declared reliable.

The next step that must be done after the overall model is analyzed for suitability is to test the suitability of the structural model (structural model fit). Structural equation compatibility test is carried out on the coefficients of structural equation by specifying a certain significant level. In summary, a summary of the measurement model match test results can be seen in Figure 3.

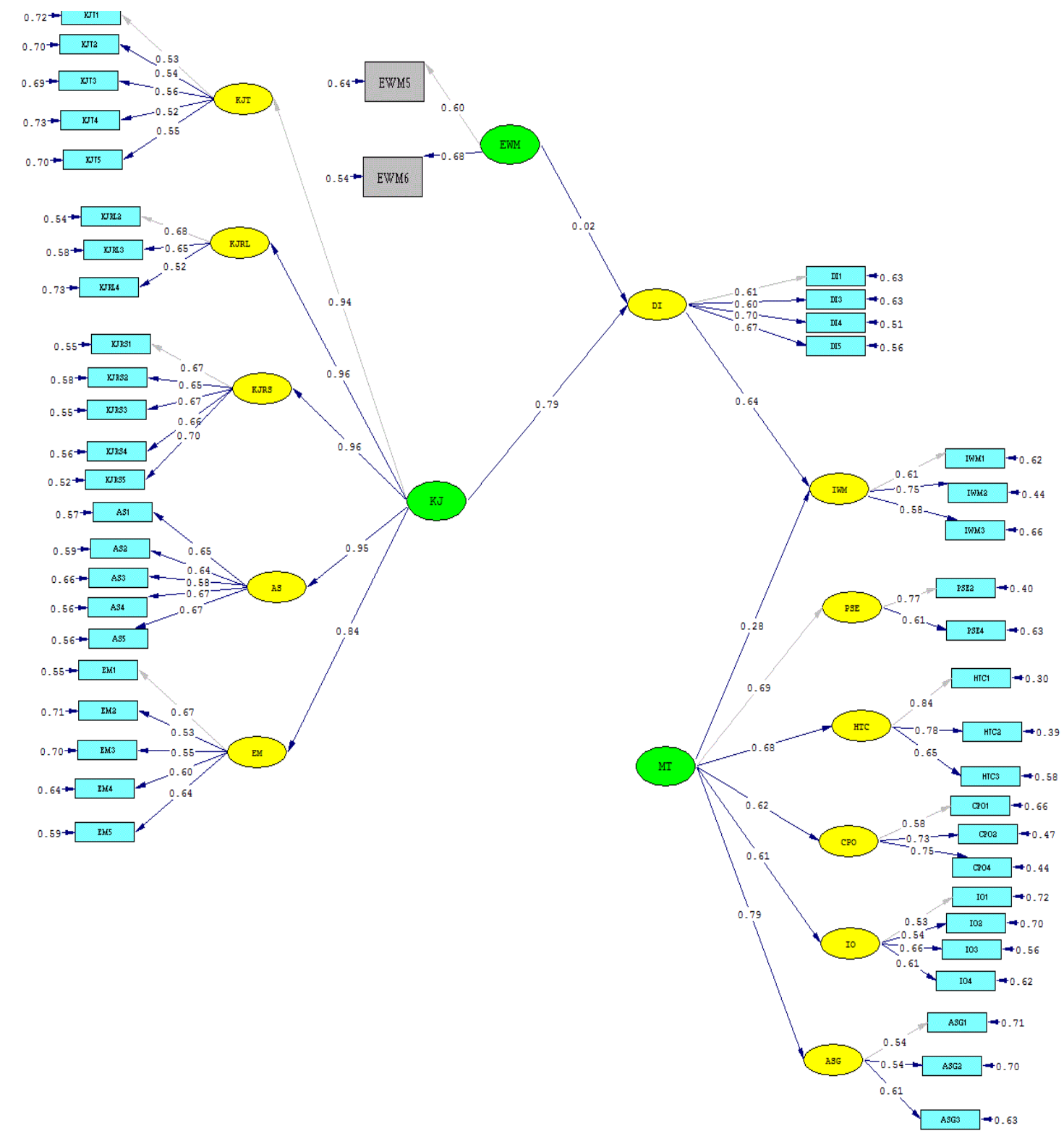

Figure 3 - SEM Measurement Model 
The results of the model fit test showed quite good results. The results of the measurement of the model's fit that showed good fit were, among others, RMSEA, NFI, IFI, $\mathrm{CFI}, \mathrm{RFI}$, and NNFI. While the measurement results that show marginal fit are GFI. The results of the measurement of the model's fit can be found in Table 1.

Table 1 - The Overall Model Fit Test Results

\begin{tabular}{lccc}
\hline \multicolumn{1}{c}{ Goodness-Of-Fit } & Cut-off-Value & \multicolumn{2}{c}{ After using } \\
\cline { 3 - 4 } & & Results & Information \\
\hline Root Mean Square Error of Approximation (RMSEA) & $\leq 0.08$ & 0.06 & Good Fit \\
Goodness Of Fit Index (GFI) & $\geq 0.90$ & 0.80 & Marginal Fit \\
Normed Fit Index (NFI) & $\geq 0.90$ & 0.91 & Good Fit \\
Incremental Fit Index (IFI) & $\geq 0.90$ & 0.95 & Good Fit \\
Comparative Fit Index (CFI) & $\geq 0.90$ & 0.95 & Good Fit \\
Relative Fit Index (RFI) & $\geq 0.90$ & 0.90 & Good Fit \\
Non Normed Fit Index (NNFI) & $\geq 0.90$ & 0.95 & Good Fit \\
\hline
\end{tabular}

Table 2 explains that all influences between variables significantly influence except the relationship between EWOM which has a positive and not significant relationship to the destination image. Service quality has a positive and significant effect on destinantion image, destimation image has a positive and significant effect on the desire to do EWOM, and motivation has a positive and significant effect on the desire to do an EWOM.

Table 2 - Estimated Model SEM Results

\begin{tabular}{cccccc}
\hline \multicolumn{2}{c}{ Influence of Variables } & Path coef. & t-val. & Conclusion \\
\hline EWM & $\rightarrow$ & DI & 0.02 & 0.29 & Not Significant $^{\text {Rejormation }}$ \\
KJ & $\rightarrow$ & DI & 0.79 & 7.23 & Significant H \\
DI & $\rightarrow$ & IWM & 0.64 & 6.79 & Significant \\
MT & $\rightarrow$ & IWM & 0.28 & 3.56 & Significant $_{1}$ \\
\hline
\end{tabular}

The test results produce findings that the first hypothesis, electronic word of mouth has a positive effect but is not significant to the destination image. This can be seen from the service quality path coefficient towards the destination image of 0.02 with a t-value of 0.29 . If seen from the results obtained, the first hypothesis is rejected. This is not in line with several previous studies which found that electronic word of mouth has a positive and significant effect on the image of a tourist destination (Suwarduki et al., 2016; Jalivand et al., 2012).

Then in testing the second hypothesis, it was found that service quality had a positive and significant effect on destination image. This can be seen from the path coefficient of 0.79 and the t-value of 7.23. These results can explain that the better value of service quality; tangible, reliability, responsiveness, assurance, and empathy will make the image of Kalibiru Nature Tourism better. These results are in line with several previous studies which prove that service quality has a positive and significant effect on the image of a tourist destination (Tosun et al., 2015; Kayat and Hai, 2014; Akroush et al., 2016; Moon et al., 2013; Sunarti and Hartini S., 2015).

The results of the testing of the effect resulted in the finding that the third hypothesis, destination image, had a positive and significant effect on the desires of Kalibiru Nature Tourism visitors to conduct EWOM. This can be seen from the path coefficient of the destination image to the desire to do EWOM of 0.64 with a t-value of 6.79. This can explain that the destination image variable positively and significantly influences the desire to do EWOM so that the second hypothesis can be accepted. This result is supported by several previous studies which prove that destination image has a positive and significant effect on a person's desire to do EWOM (Shafiee et al., 2016; Papadimitrious et al., 2015).

The results of the testing of the influence resulted in the finding that the third hypothesis, namely motivation, had a positive and significant effect on the desires of Kalibiru Nature Tourism visitors to do EWOM on social media. This can be seen from the path coefficient of motivation towards EWOM desire of 0.28 with a t-test of 3.56. These findings explain that motivation has an influence on the desire of visitors to do EWOM on their social 
media regarding the experience at Nature Tourism Kalibiru. These results are in line with previous research which proves that motivation has a positive and significant influence on someone's desire to do EWOM (Magalhaes and Musallam, 2014).

\section{CONCLUSION AND RECOMMENDATIONS}

Sources of information from the virtual world are things that need attention in spreading word of mouth. This can be due to almost all respondents visiting Kalibiru Nature Tourism based on information obtained from the internet. Respondents are active users in social media. That is because the most respondents are respondents who upload photos/videos/status on their social media at least once a week. Social media that are often used by respondents are Instagram, Whatsapp and Facebook.

Electronic word of mouth is the most widely used source of information by visitors in finding information about a tourist destination before making a visit. In this study it was found that electronic word of mouth did not have a significant relationship to the image of Kalibiru Nature Tourism. This is not in line with previous research which states that electronic word of mouth has a significant effect on the image of a tourist destination.

Service quality plays an important role in creating a good image of Kalibiru Nature Tourism. If the image of Nature Tourism has been assessed well by visitors, it will increase the desire of visitors to do EWOM on social media that contains recommendations for visiting Kalibiru Nature Tourism. When compared with the EWOM variable, service quality has a greater influence. The quality of existing services in Kalibiru Nature Tourism is good, so it needs to be maintained.

Motivation is an encouragement in visitors to upload the Kalibiru Nature Tourism to their social media. In this study it was found that motivation has a positive and significant relationship to the desire to do EWOM. If the destination image variable is associated, the destination image variable has a greater influence on the desires of visitors to do EWOM.

Referring to these conclusions, it can be implied that the management of Kalibiru Nature Tourism needs to maintain the quality of services provided to visitors. Suggestion for further research is that the researcher has to consider number of questions in the questionnaire given to respondents. If there are to many questions will cause visitors to feel disturbed in enjoying the holiday. In addition, an online questionnaire can be used to respondents so respondents are not disturbed in enjoying their tour.

In making the questionnaire, it is expected to use guidelines from previous studies which have a theme with the same theme as the object under study. Foreign tourists that visiting Kalibiru Nature Tourism are quiet interesting to be investigated to find out the reasons why choosing to visit Kalibiru Nature Tourism rather than visiting other Nature Tourism.

\section{REFERENCES}

1. Akroush MN, Jraisat LE, Kurdieh DJ, Al-Faouri RN, Qatu LT. 2016. Tourism service quality and destination loyalty - the mediating role of destination image from international tourists' perspectives. Tourism Review. 71(1): 1-31.

2. Augusty F. 2006.Metode Penelitian Manajemen. Semarang: Badan Penerbit Universitas Diponegoro.

3. Ferdinand A. 2005. Structural equation modeling dalam penelitian manajemen (Aplikasi model-model rumit dalam penelitian untuk tesis magister dan disertasi doktor). Ed ke-2. Semarang (ID): Fakultas Ekonomi UNDIP.

4. Harinaldi. 2005. Prinsip-Prinsip Statistik untuk Teknik dan Sains. Jakarta: Erlangga.

5. Dinas Pariwisata DIY, 2018. Statistik Kepariwisataan DIY 2017 di: https://visitingjogja.com/15691/statistik-pariwisata-diy-2017/

6. Jalivand MR, Samiei N, Dini B, Manzari PY. 2012. Examining the structural relationships of electronic word of mouth, destination image, tourist attitude toward destination and travel intention: An integrated approach. Journal of Destination Marketing \& Management. 1(2012): 134-143. 
7. Kayat K, Hai Md Abdul. 2013. Perceived service quality and tourists'cognitive image of a destination. Anatolia: An International Journal of Tourism and Hospitality Research. 25(1): 1-12.

8. Kemenpar, 2019. Laporan Akuntabilitas Kinerja Kementerian Pariwisata Tahun 2018. Jakarta: Kemenpar.

9. Magalhaes R, Musallam B. 2014. Investigating Electronic Word-of-Mouth Motivations in the Middle East: Twitter as Medium and Message. Journal of Electronic Commerce in Organizations. 12(3): 40-59.

10. Moon KS, Ko YJ, Connaughton DP, Lee JH. 2013. A mediating role of destination image in the relationship between event quality, perceived value, and behavioral intention. Journal of Sport \& Tourism. 18(1): 49-66.

11. Notoatmodjo S. 2010.Metodologi Penelitian Kesehatan. Jakarta: Rineka Cipta.

12. Papadimitriou D, Kaplanidou K, Apostolopoulou A. 2015. Destination Image Components and Word of mouth Intentions in Urban Tourism: A Multigroup Approach. Journal of Hospitality and Tourism Research.42(4): 503-527.

13. Prayogo RR, 2016. Electronic Word of Mouth, Destination Image, and Satisfaction Toward Visit Intention: An Empirical Study in Malioboro Street, Yogyakarta. Advances in Social, Science, Education and Humanities Research. 81: 209-218.

14. Shafiee MM, Tabaeeian RA, Tavakoli H. 2016. The Effect of Destination Image on Tourist Satisfaction, Intention to Revisit and WOM: An Empirical Research in Foursquare Social Media. Israfan:10th International Conference on e-Commerce in Developing Countries: with focus on e-Tourism (ECDC).

15. Sunarti, Hartini S. 2015.The Influence of Functional Destinations Image and Psychological Destinations Image Toward the Behaviorallntentions on Ecotourism of Foreing Tourists in Lombok. International Review of Management and Business Research. Vol 4(3): 621-632.

16. Thurau TH, Gwinner KP, Walsh G, Gremler GG. 2004. Electronic Word of Mouth via Consumer-Opinion Platforms: What Motivates Consumers to Articulate Themselves on the Internet?. Journal of Interactive Marketing. Vol 18(1): 38-52.

17. Tosun C, Dedeoglu BB, Fyall A. 2015. Destination service quality, affective image and revisit intention: The moderating role of past experience. Journal of Destination \& Management. 4(4): 222-234. 